\title{
Analysis of Variance Fruit Yield and its Components in Sponge Gourd [Luffa cylindrica (Roem.) L.]
}

\author{
Sanjeev Kumar ${ }^{1 *}$, V.J. Bhatiya ${ }^{2}$, Sanjay Kumar ${ }^{3}$, Vidya Bhati ${ }^{4}$ and Dushyant Parihar $^{5}$ \\ ${ }^{1}$ Department of Genetics and Plant Breeding, ${ }^{2}$ Department of Seed Science and Technology, \\ Junagadh Agricultural University, Junagadh-362001 (Gujrat), India \\ ${ }^{3}$ Department of Vegetable Science, CCSHAU, Hisar, Haryana, India \\ ${ }^{4}$ Department of Horticulture, SKRAU, Bikaner, India \\ ${ }^{5}$ Department of Applied Plant Science (Horticulture), Babasaheb Bhimrao Ambedkar Univ., \\ Lucknow, India \\ *Corresponding author
}

\section{A B S T R A C T}

\begin{tabular}{|l|}
\hline Ke y w or d s \\
$\begin{array}{l}\text { Fruit yield, Genetic } \\
\text { analysis of variance, } \\
\text { Sponge gourd }\end{array}$ \\
\hline Article Info \\
\hline Accepted: \\
02 May 2018 \\
Available Online: \\
10 June 2018 \\
\hline \hline
\end{tabular}

\begin{abstract}
A $10 \times 10$ diallel analysis excluding reciprocals in sponge gourd (Luffa cylindrica (Roem.) L.) revealed highly significant mean squares due to genotypes for all characters except days to first picking and fruit girth. The mean square due to parents was highly significant for node to first female flower, number of primary branches per vine, ten fruit weight, fruit girth, fruit yield per vine and significant for node to first male flower. The mean square due to hybrids was highly significant for days to open first female flower, node to first female flower, node to first male flower, length of vine, number of primary branches per vine, number of fruits per vine, ten fruit weight, fruit length, fruit yield per vine and fruit fly infestation. Mean square due to parents $V s$ hybrids were highly significant for node to first female flower, node to first male flower, length of vine, ten fruit weight, fruit length, fruit yield per vine and would be exploited for heterosis breeding in sponge gourd.
\end{abstract}

\section{Introduction}

Sponge gourd [Luffa cylindrica (Roem.) L.] is one of the popular cucurbitaceous vegetable crops grown in tropical and sub-tropical parts of world.

In India, sponge gourds are used for food at about two week after flowering when they are still physiologically immature, at what is called 'economic maturity', and for industrial purposes at about 60 to 65 days after flowering when physiologically mature (Zhang et al., 2007).

Diallel analysis has generally been used to assess analysis of variance governing the expression of quantitative traits. An attempt has been made in the present investigation to study the genetics of fruit yield and its contributing traits through component analysis of ten parental diallel cross in sponge gourd. 


\section{Materials and Methods}

The experimental material comprised of parents and their $F_{1} s$ derived by crossing ten different genotypes of sponge gourd (Pusa Chikni, GSG 1, ASGS 08-40, ASGS 08-38, ASGS 08-37, ASGS 08-39, ASGS 06-30, ASGS 02-12, JSG 05-7 and JSG 05-4) in a diallel fashion excluding reciprocals. The experiment was laid out in a Randomized Block Design with three replications during summer 2011. The plants were spaced at a distance of $2.0 \mathrm{~m}$ between rows and $1.0 \mathrm{~m}$ within a row.The analysis of variance was performed to test the significance of difference among the genotypes for all the characters following fixed effect model as suggested by Panse and Sukhatme (1985).

$\mathrm{Y}_{\mathrm{ij}}=+\mathrm{g}_{\mathrm{i}}+\mathrm{r}_{\mathrm{j}}+\mathrm{e}_{\mathrm{ij}}$

$\mathrm{i}=1,2, \ldots, \ldots, \mathrm{g}$ and

$\mathrm{j}=1,2, \ldots, \ldots, \mathrm{r}$

Where, $Y_{i j}=$ Value of $i^{\text {th }}$ genotype in $j^{\text {th }}$ replication Population mean, $g_{i}=$ An effect of $i^{\text {th }}$ genotype, $r_{j}=$ An effect of $j^{\text {th }}$ replication, $e_{i j}$ $=$ Uncontrolled variation associated with $i^{\text {th }}$ genotype and $\mathrm{j}^{\text {th }}$ replication. Analysis of variance based on this mathematical model leads to the variance components. The mean square due to genotypes and its sub divisions were tested against error mean squares $\left(\mathrm{M}_{6}\right)$ by F-test.

\section{Results and Discussion}

In the present investigation, the character wise data of parents and hybrids were subjected to analysis of variance for the experimental design. Analysis of variance for different characters is presented in Table 1. Perusal of data revealed highly significant mean squares due to genotypes for all characters except days to first picking and fruit girth indicating that experimental material had sufficient genetic variability for these characters. The genotypic variance was further partitioned into variance due to parents, hybrids and parents $V s$ hybrids. The mean square due to parents was highly significant for node to first female flower, number of primary branches per vine, ten fruit weight, fruit girth, fruit yield per vine and significant for node to first male flower. The mean square due to hybrids was highly significant for days to open first female flower, node to first female flower, node to first male flower, length of vine, number of primary branches per vine, number of fruits per vine, ten fruit weight, fruit length, fruit yield per vine and fruit fly infestation. Mean square due to parents $v s$. hybrids were highly significant for node to first female flower, node to first male flower, length of vine, ten fruit weight, fruit length, fruit yield per vine.

The analysis of variance revealed significant differences among the mean squares due to genotypes except days to first picking, fruit girth and fruit yield per vine, parents except days to open first female flower, days to first picking, length of vine, number of fruits per vine and fruit length; hybrids for all the characters except days to first picking, fruit girth, fruit yield per vine. Similar findings were also reported by Zang et al., (2008) in sponge gourd. The parents $v s$. hybrids except days to open first female flower, days to first picking, number of fruits per vine, fruit girth and fruit yield per vine.

This indicated the presence of considerable amount of genetic variability among the parents and the material was most useful for the study of manifestation of heterosis and genetic parameters involved in the inheritance of different traits and fruit fly infestation and significant for number of primary branches per vine indicating that the performance of hybrids as a group was different than that of parents for most of the characters. This revealed the presence of considerable heterosis due to directional dominance. 
Table.1 Analysis of variance showing mean squares for fruit yield and it's contributing characters in sponge gourd

\begin{tabular}{|c|c|c|c|c|c|c|c|c|c|c|c|c|c|}
\hline $\begin{array}{l}\text { Source of } \\
\text { variation }\end{array}$ & df & $\begin{array}{l}\text { Days to } \\
\text { open first } \\
\text { female } \\
\text { flower }\end{array}$ & $\begin{array}{c}\text { Node to } \\
\text { first } \\
\text { female } \\
\text { flower }\end{array}$ & $\begin{array}{l}\text { Node } \\
\text { to first } \\
\text { male } \\
\text { flower }\end{array}$ & $\begin{array}{l}\text { Days to } \\
\text { first } \\
\text { picking }\end{array}$ & $\begin{array}{l}\text { Length of } \\
\text { vine } \\
\text { (m) }\end{array}$ & $\begin{array}{l}\text { No. of } \\
\text { primary } \\
\text { branches } \\
\text { per vine }\end{array}$ & $\begin{array}{l}\text { No. of } \\
\text { fruits } \\
\text { per vine }\end{array}$ & $\begin{array}{l}\text { Ten fruit } \\
\text { weight (g) }\end{array}$ & $\begin{array}{l}\text { Fruit } \\
\text { length } \\
\text { (cm) }\end{array}$ & $\begin{array}{l}\text { Fruit } \\
\text { girth } \\
\text { (cm) }\end{array}$ & $\begin{array}{c}\text { Fruit } \\
\text { yield per } \\
\text { vine }(\mathrm{kg})\end{array}$ & $\begin{array}{l}\text { Fruit fly } \\
\text { infestation } \\
(\%)\end{array}$ \\
\hline Replications & 2 & 12.63 & 1.50 & 0.15 & $25.88^{*}$ & 0.02 & 0.02 & $2.40^{*}$ & 9870.94 & 2.61 & 0.10 & $0.07 *$ & 3.78 \\
\hline Genotypes & 54 & $22.98 * *$ & $5.69 * *$ & $1.38 * *$ & 6.24 & $0.34 * *$ & $0.39 * *$ & $0.30 * *$ & $62096.59 * *$ & $5.68 * *$ & 0.70 & $0.32 * *$ & $44.52 * *$ \\
\hline Parents & 9 & 12.98 & $6.70 * *$ & $0.91 *$ & 6.05 & 0.13 & $0.21 * *$ & 0.47 & $45556.40 * *$ & 1.46 & $3.35 * *$ & $0.28 * *$ & 3.18 \\
\hline Hybrids & 44 & $25.06 * *$ & $3.27 * *$ & $1.26 * *$ & 6.49 & $0.37 * *$ & $0.31 * *$ & $1.57 * *$ & $65749.79 * *$ & $15.17 * *$ & 0.20 & $0.42 * *$ & $47.83 * *$ \\
\hline $\begin{array}{l}\text { Parents Vs } \\
\text { Hybrids }\end{array}$ & 1 & 21.49 & $97.81 * *$ & $9.93 * *$ & 1.44 & $0.78 * *$ & $0.25^{*}$ & 1.07 & $50211.98 * *$ & $138.39 * *$ & 0.04 & $1.56^{* * *}$ & $293.53 * *$ \\
\hline Error & 108 & 9.24 & 1.29 & 0.41 & 6.93 & 0.10 & 0.05 & 0.63 & 3254.85 & 4.15 & 0.74 & 0.02 & 10.11 \\
\hline
\end{tabular}

$*$, ** significant at $5 \%$ and $1 \%$, respectively 


\section{Acknowledgement}

We are very much thankful to Staff of department of Genetics and Plant Breeding, JAU, Junagadh for their kindly help.

\section{References}

Panse, V. G. and Sukhatme, P. V., (1985). Statistical methods for Agricultural Workers, (Third edition). Indian Council of Agricultural Research, New Delhi.
Zhang, S., $\mathrm{Hu}$, Jin and $\mathrm{Xu}$, Shengchun, (2008). Developmental genetic analysis of fruit shape traits under different environmental conditions in sponge gourd (Luffa cylindrical (L.) Roem. Violales, Cucurbitaceae). Genetics and Molecular Biology, 3:704-710.

Zhang, S., Huj, Zhang, C. F., Guan, Y. J., Zhang, Y., (2007). Genetic analysis of fruit shape traits at different maturation stage in sponge gourd. J. Zhejang Uni. Sci., 8: 338-344.

\section{How to cite this article:}

Sanjeev Kumar, V.J. Bhatiya, Sanjay Kumar, Vidya Bhati and Dushyant Parihar. 2018. Analysis of Variance Fruit Yield and its Components in Sponge Gourd [Luffa cylindrica (Roem.) L.]. Int.J.Curr.Microbiol.App.Sci. 7(06): 383-386.

doi: https://doi.org/10.20546/ijcmas.2018.706.043 